\title{
INTERFACE BETWEEN TWO IMMISCIBLE LIQUID ELECTROLYTES: A REVIEW
}

\author{
PETR VANÝSEK ${ }^{* 1}$ AND LUIS BASÁEZ RAMÍREZ ${ }^{2}$ \\ ${ }^{\prime}$ Northern Illinois University, Department of Chemistry and Biochemistry, DeKalb, IL 60115, USA. \\ ${ }_{2}^{2}$ Departamento de Química Analitica e Inorgánica, Facultad de Ciencias Químicas, Universidad de Concepción, Chile.
} (Received: 13 December 2007 - Accepted: 22 April 2008)

\begin{abstract}
An overview on electrochemistry on the interfaces between two immiscible electrolyte solutions is given.

Keywords: Review, ITIES, liquid-liquid interface, ion transfer, electron transfer, phase transfer catalysis, analytical applications, interfacial structure, DIGISIM, modeling, X-ray reflectivity, double layer, immiscible liquids, electrochemistry.
\end{abstract}

\section{BACKGROUND}

The concept of immiscibility of certain liquids, such as oil and water, must have been known to the humankind for millennia, and it must have captivated early scientists just as much as it fascinates by its specific properties scientists today. In our review we will focus on a specialized interface between two immiscible liquids, an interface arising between two immiscible electrolyte solutions. An electrolyte, a medium with ionic conductivity and mobile charge carriers, introduces to the system of two immiscible phases additional property not observed on an oil-water interface. Since the two phases are now conductive and charge between the two phases can achieve equilibrium through ion transport at the interface, the ionic conductivity of both the phases imparts electrical potential difference on such interface.

This interface, the interface between two immiscible electrolytes (ITIES), has some functional similarities with other types of interfaces. An interface is defined as a boundary between two distinct phases. Hence, there is an interface between a liquid and the glass wall of the container holding the liquid; there is an interface between metal and liquid (for example copper metal and aqueous solution of copper sulfate); there is an interface between water and some organic solvents (for example nitrobenzene or 1,2-dichloroethane).

From the electrochemical thermodynamic point of view the copper metal/copper sulfate solution interface is treated in a fairly simple textbook manner. The interface is described as a half cell and its potential is given by the Nernst equation, utilizing the activity of the copper ions in the solution and the standard reduction potential of $\mathrm{Cu}^{2+}$. When the potential of this interface is studied in more detail it becomes obvious that the interfacial potential is actually maintained by equilibrium between $\mathrm{Cu}^{2+}$ ions in the aqueous solution and the activity, albeit abstract, of the copper ions in the metal. The general reversible equilibrium

$$
\mathrm{Cu}^{2+}+2 \mathrm{e} \rightleftarrows \mathrm{Cu}
$$

is the prerequisite for maintaining a steady and defined potential. In fact, similar equilibria, e.g., between the activity of $\mathrm{H}_{3} \mathrm{O}^{+}$in solution and activity of $\mathrm{OH}^{-}$groups on surface of hydrated glass of a glass electrode is the principle of the $\mathrm{pH}$ electrode. In short, any system that has an interface on which equilibrium of charged species is dynamically established, will be a site of an interfacial potential. By following this idea, it can be similarly envisioned that an interface between two immiscible solutions, of which each contains certain activity of a particular ion $\left(\mathrm{K}^{+}\right.$, for example) will be a site of a potential difference driven by the relative activities of potassium ion in each of the two phases. An example of this is, in fact, an ion selective electrode based on a liquid membrane in which the analyte is an aqueous solution containing dissolved potassium ions; the sensing side is an organic solvent. An organic solvent will not typically dissolve potassium ions. However, making them more lipophillic, for example, by complexation with valinomycin, can make them soluble. This is known as facilitated transport.

With proper setup, the interface between the two liquids can be made into a boundary that responds, for electroanalytical purposes, like an electrode. However, the distinction is that instead of reduction or oxidation of a species on the electrode surface, a transport of a charged species thought the interface, governs the observed current flow.
In order to observe ion transport across the interface due to applied potential, it is first necessary to be able to apply appropriate potential on the interface, i.e., the interface has to be made a polarizable interface. In order to make a polarizable interface, it is first necessary to make the two phases conductive to be able to apply potential from external electrodes. This is done by dissolving suitable supporting electrolyte salts in each phase. To make the interface polarizable, at least in a certain potential window, the salts dissolved in the respective phase must be preferentially soluble in one phase, but not in the other. The two salts often used are hydrophilic $\mathrm{LiCl}$, which is used as the supporting electrolyte for the aqueous phase and tetrabutylammonium tetraphenylborate (TBATPB), which is lipohilic and is used as the supporting electrolyte for the organic phase. Nitrobenzene or 1,2-dicholoroethane (DCE) are used very often as the organic phase. Fig. 1 shows the potential window in which such interface is polarizable.

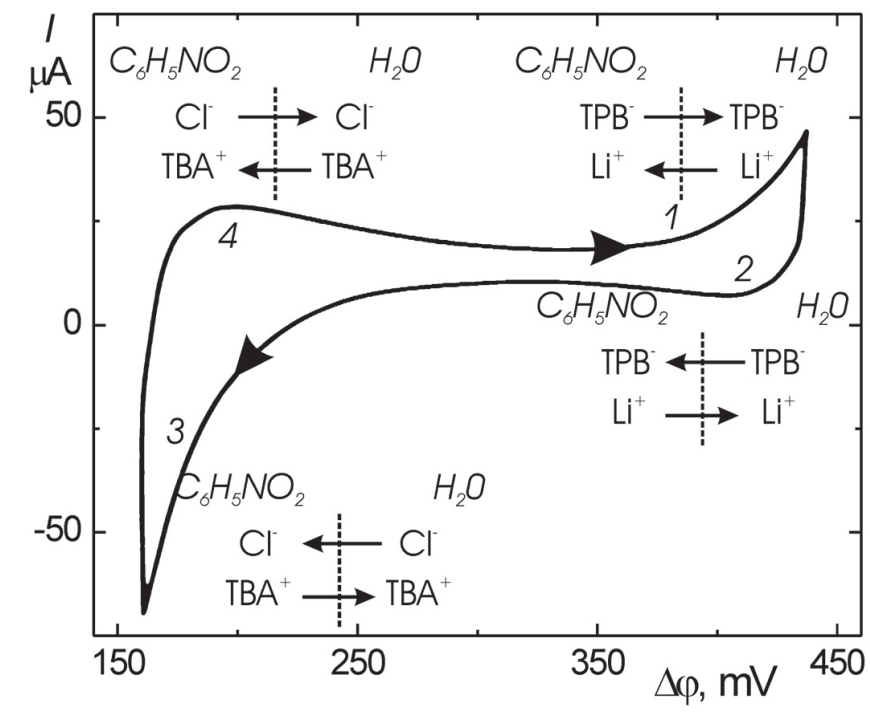

Figure 1. Curve of ITIES for a supporting electrolyte

The figure is a cyclic voltammogram, which shows the current flowing through the interface in response to the applied potential. Within the potential window, only little current flows, due mostly to charging of the interface (charging current). Outside the window the ions of the supporting electrode begin to transport into the opposite phase, contributing to the increasing background current. Since it is traditional to assign the polarity of the interface to the aqueous phase (as if the nonaqueous phase were grounded), the right hand side of the curve in Fig. 1 corresponds to the aqueous phase becoming increasing more positive. As the polarization continues (1 on the curve), TPB begins to transport from nitrobenzene to water and $\mathrm{Li}^{+}$begins to be transported form water to nitrobenzene. The relative contribution of the lipophilic anion and the hydrophilic cation depend on the ranking of these ions on the scale of the Gibbs energies of transfer ${ }^{1}$; since they are similar, both ions contribute 
to the observed background current. After switching the direction of the scan ( 2 on the curve), tetraphenylborate (TPB-) previously transported into water crosses again back into nitrobenzene and $\mathrm{Li}^{+}$from nitrobenzene crosses back to water. As the cycle continues through the window of polarizability, the current is mostly due to the charging of the interface; eventually, the aqueous phase is becoming less and less positive with respect to the organic phase (3 on the curve) and transport of $\mathrm{Cl}^{-}$from water to nitrobenzene and transport of tetrabutylammonium $\left(\mathrm{TBA}^{+}\right)$from nitrobenzene to water is observed. Finally, after the potential switch ( 4 on the curve) the previously transported ions return to their phase of origin, $\mathrm{Cl}^{-}$crosses back to water and $\mathrm{TBA}^{+}$crosses to nitrobenzene.

The potential at which the ion transfer across the interface happens is related to the Gibbs energy of transfer. Thermodynamically, this energy and the corresponding potential are normalized to the standard Gibbs energy of transfer. It is a function of the particular ion, as well as a function of the solvent pair studied. These values are available in various tables including a good web based data base $^{2}$ and Table I gives an example of some values for individual ions transferring from water to nitrobenzene.

Table I.- Standard potentials of transfer $\Delta^{\alpha} \beta \phi^{0}$ for selected individual ions from water (phase $\alpha$ ) to nitrobenzene (phase $\beta$ )

$\begin{array}{lr}\mathrm{Ion} & \Delta^{\alpha} \beta \phi^{\mathrm{o}}(\mathrm{mV}) \\ \mathrm{Li}^{+} & 395 \\ \mathrm{UO}_{2}^{2+} & 373 \\ \mathrm{Mg}^{2+} & 361 \\ \mathrm{Na}^{+} & 354 \\ \mathrm{Fe}^{3+} & 319 \\ \mathrm{~K}^{+} & 242 \\ \mathrm{Rb}^{+} & 201 \\ \mathrm{Cs}^{+} & 159 \\ \mathrm{Choline}^{+} & 117 \\ \text { Acetylcholine }^{+} & 49 \\ \mathrm{TMeA}^{+} & 35 \\ \mathrm{TBA}^{+} & -248 \\ \mathrm{TPB}^{-} & 372 \\ \text { Picrate }^{-} & 47 \\ \text { Dodecylsulfate } & -43 \\ \mathrm{ClO}_{4}^{-} & -83 \\ \mathrm{Cl}^{-} & -324\end{array}$

The values for individual ions cannot be fundamentally determined separately, one ion is always related to another in a chain of measurements. Therefore, an assumption has been made that in the process of determining the values for the cation and the ion of tetraphenylarsonium tetraphenylborate both will have equal values, based on their similar sizes ${ }^{3-6}$.

It is desirable to have the operating window as wide as possible. Although TBATPB is traditionally used, more lipophilic salt has recently seen increase in use (Fig. 2), the very lipophilic

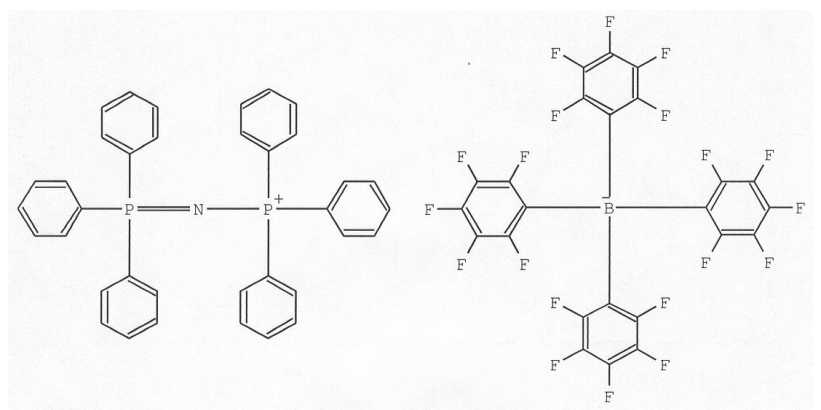

Figure 2. Bis(triphenylphosporanylidene)ammonium tetrakis (pentafluorophenyl)borate

bis (triphenylphosporanylidene) ammonium tetrakis (pentafluorophenyl) borate (BTPPATPFB). This salt has desirable wider potential window than TBATPB. Its disadvantage is that it is rather expensive and so far it has to be prepared rather than purchased. The preparation is not particularly involved and is described in a skeletal form by Fermin et al . The process involves metathesis of stoichiometric amounts BTPPACl and LiTPFB dissolved in 2:1 mixture of methanol and water, followed by recrystallization from hot acetone. The initial precipitation requires additional amounts of the methanol-water mixture, therefore it is not necessary to dissolve the starting material in least amount of solvent. The solubility of the product is much higher in hot acetone than in cold, so recrystallization is pretty simple. The melting point of our product was $223-225{ }^{\circ} \mathrm{C}$. It should be noted that the acetone precipitate should be washed by copious amounts of 2:1 mixture of methanol and water, to rinse out any starting material, which otherwise causes large background current.

In the presence of an ion that can partition between the two phases it is possible to obtain a voltammogram similar to that of a redox couple. Fig. 3 shows such case in which a cation with potential of transfer equal to $159 \mathrm{mV}$, corresponding to the cesium ion, is being transferred across the interface.

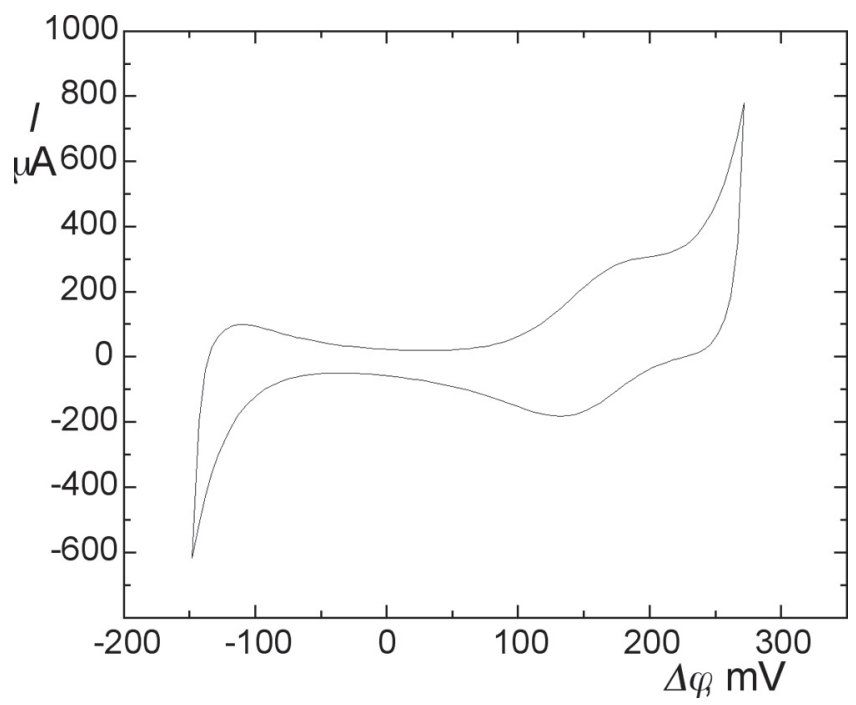

Figure 3. Transfer of a $\mathrm{Cs}^{+}$ion - DIGISIM simulated result.

It should be noted that the diffusion controlled process is described by the same equations as a redox process - transfer across the interface is considered fast compared to the diffusion control in both phases towards and away from the interface, therefore the same math applies. However, the interface does not experience a redox process. The difference between the diffusion controlled redox and ITIES situation are compared in Fig. 4.

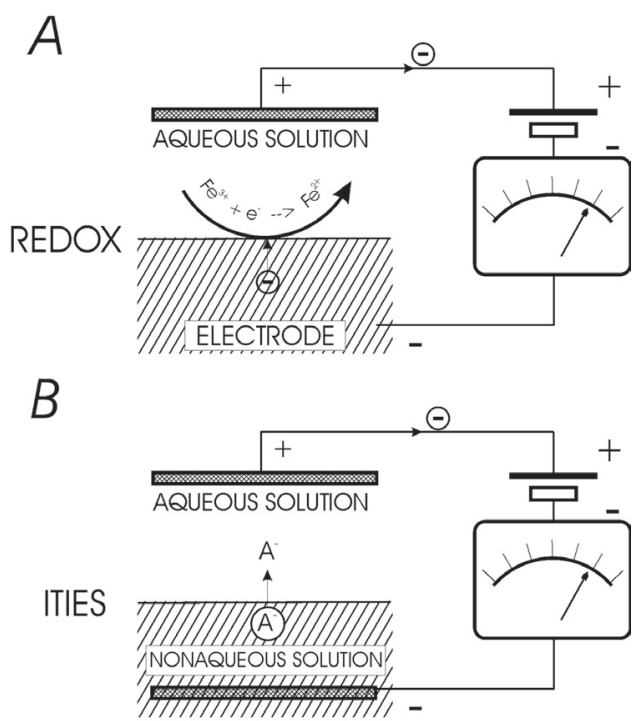

Figure 4. Comparison between ITIES and a redox system 
In case $A$ when negative potential is applied at the working electrode, electron transfer takes place at the solution/metal electrode interface, iron(III) is reduced to iron(II) and an electron moves "upwards" from the electrode to the now-reduced iron ion. As a consequence, negative charge (arrow) flows through the outside electrical circuit. In case $B$, when negative potential is applied at the bottom (nonaqueous) phase in which ion $\mathrm{A}^{-}$is present, the negatively charged ion moves "upwards" from the nonaqueous phase to the aqueous phase. As a consequence, negative charge (arrow) flows through the outside electrical circuit. Although the interfacial process in case $A$ and $B$ are different, the same effect, current flow in the external electrical circuit, is observed.

The potential on the interface, as governed by a single ion that can partition between the two phases in described by equation

$$
\Delta_{o}^{w} \varphi_{i}=\Delta_{o}^{w} \varphi_{i}^{0}+\frac{R T}{z_{i} F} \ln \frac{a_{i}(o)}{a_{i}(w)}
$$

which is similar in its appearance to the Nernst equation and in fact, it can be derived by using the Nernst formalism. It is useful in situations where the other ions, including the counterions, are well confined in their respective original phases. However, when more that one ion participates in the equilibrium, the equation becomes rather complicated ${ }^{8}$ :

$$
\sum_{i=1}^{j} \frac{n_{i} m_{i}}{V^{\alpha}+V^{\beta}\left(\frac{\gamma_{i}^{\alpha}}{\gamma_{i}^{\beta}}\right) \exp \left[\frac{n_{i} F}{R T}\left(\Delta \varphi-\varphi_{i}^{o}\right)\right]}=0
$$

where $\mathrm{V}^{\alpha}$ and $\mathrm{V}^{\beta}$ are the volumes of the phases $\alpha$ and $\beta$ (usually water, oil), $\Delta \phi$ is the interfacial potential, $\Delta \phi^{\circ}$ is the standard potential of transfer for the individual ion (for example listed in Table I), $\mathrm{m}$ is the number of moles of each of the ions, $n$ is the charge (signed) of the respective ion, and $\gamma$ is the activity of the ion in the respective phase, $\alpha$ or $\beta$. For more than two species this equation cannot be solved explicitly. However, with the help of an iterative solver it can be successfully solved and used to calculate the interfacial potential from the known values of the standard potentials, or, it can be used also to solve for a particular unknown standard potential, if the partition coefficients are known?.

When the immiscible phases are in contact for sufficient length of time, equilibrium according to the equation (3) will be established and there will be no net current flow through the system. However, when such interface is polarized from an external source, new equilibrium has to be established and this can happen only trough reequilibration of the phases, by ion transport from one phase to another and therefore, by current flow. In the most basic form the expression describing the current at the interface is

$I=A F k\left\{c_{i}(w) \exp \left(\frac{\alpha F\left(\Delta \varphi-\varphi_{i}^{o}\right)}{R T}\right)-c_{i}(o) \exp \left(\frac{(\alpha-1) F\left(\Delta \varphi-\varphi_{i}^{o}\right)}{R T}\right)\right\}$

where $\mathrm{A}$ is the interfacial area, $\mathrm{F}$ is the Faraday constant, $\mathrm{k}$ is the formal rate constant of the transfer, $\alpha$ is the charge transfer coefficient, $c_{i}(w)$ and $c_{i}(o)$ are the concentration of ion $i$ in the aqueous and the oil phase respectively,

$\varphi_{i}^{O}$ s the standard potential of transfer of ion $i$ and $\Delta \varphi$ is the potential difference applied on the interface. This equation is in its formalism the same as the Butler-Volmer equation written for redox processes. A more involved equation can be written to include the Frumkin correction, which, as has been shown by d'Epenoux et $a l^{10}$, applies also to ITIES. This more complex equation can be found for example in the review publication ${ }^{11}$.

The interfaces between two immiscible electrolytes are of continuing interest to many researchers, because of their relevance to such diverse applications such as ion-pairing ${ }^{12,13}$, charge-transfer ${ }^{14,15}$, adsorption-desorption ${ }^{15}$, complexation ${ }^{16}$, extraction ${ }^{17}$ acid-base processes ${ }^{18}$, catalysis ${ }^{19}$, micellar chemistry ${ }^{20}$, modeling of interactions at biological cell membranes ${ }^{21-24}$, solvation dynamics ${ }^{25}$ and fundamental studies of the nature of such interface ${ }^{26}$.

Ion distributions in electrolyte solutions near charged interfaces underlie processes as diverse as electron and ion transfer at biomembranes and redox processes at mineral-solution interfaces, and also influence many practical applications in analytical chemistry and electrochemistry ${ }^{27-30}$.

The current associated with the ion transport across the interface is governed by the same mass transport limitations as are redox processes on a metal electrode/solution interface, namely, in unstirred systems with fast electron transport the current governing step is diffusion. As long as the transport of the ion on ITIES is fast (which it usually is) then the current associated with the ion transport is governed by the same diffusion equations. Therefore, we used successfully the modeling software DIGISIM ${ }^{31}$ (Bioanalytical Systems) to generate voltammograms which well agree with the voltammograms obtained from an experiment. It is important to realize that the potential window in ITIES is much narrower than is the typical working range of an ideally polarizable electrode. Therefore, the potential of transfer of the supporting electrolytes has to be included in the CV properties as well. To generate a curve of the supporting mechanism we chose four mechanisms; reduction of a species by one electron, with the redox potential being equal to the standard potential of transport for the supporting electrolytes, i.e., $\mathrm{Cl}^{-}$, $\mathrm{Li}^{+}, \mathrm{TBA}^{+}$and $\mathrm{TPB}$. In practice, it is sufficient to include only the cation and anion which are the more restrictive, in this case $\mathrm{TBA}^{+}$and $\mathrm{TPB}^{-}$. To visualize transport of a semihydrophilic ion across an interface, additional mechanism (again, a reduction) is added, with the redox potential $\mathrm{E}_{\mathrm{o}}$ in the software set to the standard potential of transfer for the semihydrophilic ion. Fig. 3 shows such simulation. The potentials for the restrictive ions of the supporting electrolytes were set to $0.372 \mathrm{~V}\left(\mathrm{TPB}^{-}\right)$and $-0.248 \mathrm{~V}\left(\mathrm{TBA}^{+}\right)$[Compare to the standard potentials in Table I.]. The concentration of these ions was $0.1 \mathrm{~mol} /$ 1, value typical for such experiments. The potential of the semihydrophobic ion was $0.159 \mathrm{~V}$, chosen for illustration to fall between the potentials of the supporting electrolytes. This corresponds to the potential of transport of cesium ion between water and nitrobenzene. Its concentration was $1.0 \mathrm{mmol} / \mathrm{l}$. The scan rate was $25 \mathrm{mV} / \mathrm{s}$. The actual scan was between -0.143 and $+0.272 \mathrm{~V}$. Additional adjustable parameter is the diffusion coefficient of the ion. We used the default value, $1 \times 10^{-5} \mathrm{~cm}^{2} / \mathrm{s}$, which is somewhat higher than would be the actual value. However, since the diffusion coefficient enters into the equations as a square root, the results are not very sensitive to the exact value and for demonstration purpose of suitability of DIGISIM to simulate ITIES curves this is adequate.

An example of the electrochemical cell used for the experiments with ITIES is shown in Fig. 5. It has some degree of complexity, because the issue of a 4-electrode potentiostat and the issue of a reference electrode have to be addressed.

In typical electrode electrochemistry a 3-electrode potentiostat is used, with the working, the counter and the reference electrode. In principle, two electrodes are needed; the 3-electrode setup allows the reference electrode not to pass any current and therefore avoid polarization, and the current is supplied by the counter (or auxiliary) electrode. Such setup allows to compensate for the resistance of the solution. In ITIES we have to content with two sources of resistance, both the aqueous and the nonaqueous solutions, with the ITIES (functional equivalent of the electrode) sandwiched between them. Therefore a special potentiostat is used, which has input for 2 reference electrodes, rather than for one. Additionally, two counter electrodes are used. A number of commercial potentiostats allow this connection either directly or after some modifications. Solartron 1286 or 1287 is an example of the instrument used in our laboratory.

The cell is operated in such a way that the reference electrode inputs from the instrument are connected to the cell reference electrodes, which then extend as Luggin capillaries to the vicinity of the L/L interface, marked ITIES in the diagram. The two counter electrodes are connected to platinum flag electrodes separated from the working solutions by a glass frit that prevents any electrochemical products formed on the counter electrodes from contamination of the interface. It should be noted that although there is no redox process occurring on the interface, as long as there is current flowing through the cell, redox processes (usually oxidation or reduction of the solvents) is taking place on the platinum surface of the counter electrodes.

The potential of the whole cell, which includes the interface, is monitored by the pair of the reference electrodes. The aqueous reference electrode is usually simple $\mathrm{Ag} / \mathrm{AgCl}$ electrode, which works well, because in most cases the solution contains chloride, which pins the $\mathrm{Ag} / \mathrm{AgCl}$ potential to a defined value. The reference electrode for the non-aqueous phase is more involved. It is a system with two interfaces. The actual metallic connection is realized 
by an $\mathrm{Ag} / \mathrm{AgCl}$ electrode, immersed in aqueous solution of chloride. This chloride has a counterion which is the same as is the cation in the nonaqueous phase. Therefore, if the nonaqueous solution contains TBATPB, then the aqueous solution will contain TBACl. This solution is then in contact with the nonaqueous solution forming a reference interface; the two solutions in contact have a common cation ( $\mathrm{TBA}^{+}$in this case), which equilibrates between the two phases and sets up the interfacial potential according to equation (2). Therefore, the potential applied by the potentiostat and reported on the voltammograms is not usually the "standard potential of transfer;" rather, it is a potential that is the sum of the interfacial potential, the potential of the two reference electrodes and the potential of the reference interface.

The interface should be positioned between the two Luggin capillaries. Different means of achieving this are possible. We are using a screw driven piston that allows fine change of volume in the lower part of the cell, facilitating thus adjustment of the interface.

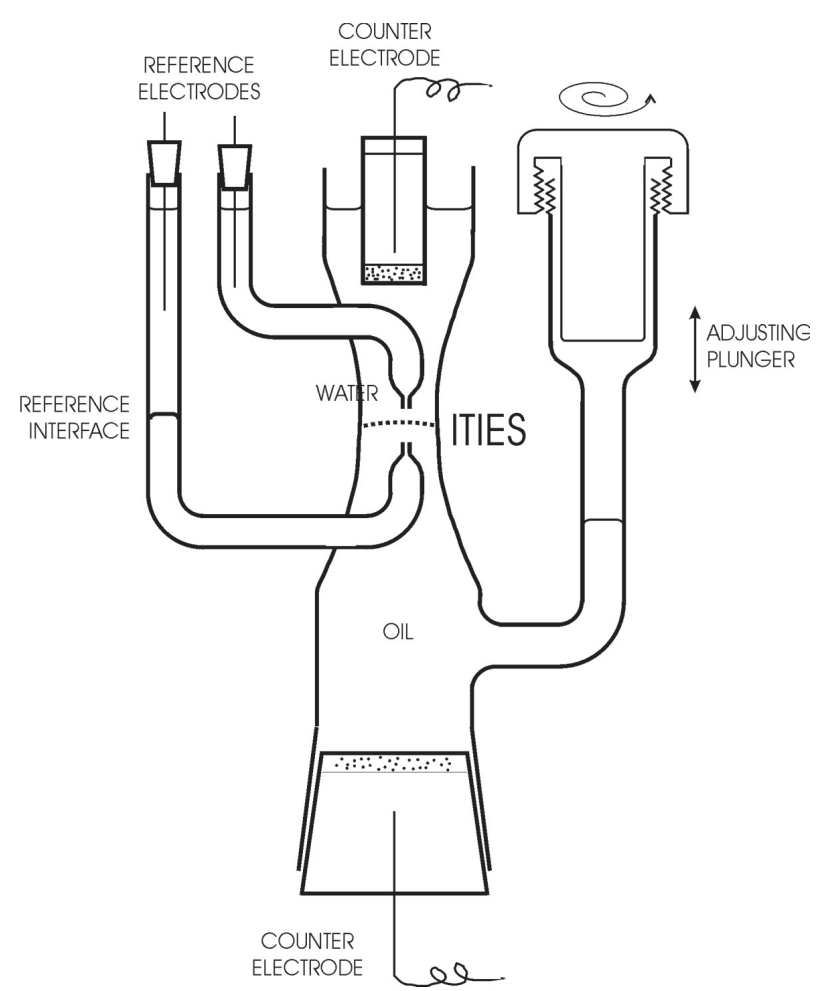

Figure 5.- Diagram of the four-electrode cell used for ITIES studies

\section{Analytical applications}

Sun and Vanýsek ${ }^{32}$ demonstrated that the interface could be used for determination of lead (II) ion by its transport across the interface. Because lead (II) itself is quite hydrophilic, the transport must be facilitated by a ligand former, such as polyethylene glycol.

The class of compounds seeing recent interest, the dendrimers, were also investigated on the liquid-liquid interfaces ${ }^{33}$. In particular, it was the nonredox active species, poly(propylenimine) and poly(amidoamine), for which transfer across (acidified water)/1,2-dichloroethane interface was a viable electroanalytical technique, since redox voltammetry is not possible. ITIES voltammetry allowed low micromolar detection of dendrimers. It was observed that the electrochemistry depended on the dendrimer family, the generation number, and the experimental $\mathrm{pH}$.

ITIES can be also successfully used for liquid-liquid extraction ${ }^{17,34,35}$. Jain et $a^{36}$. demonstrated the use of calixarene compound to preconcentrate and transport lanthanum(III) ion. Transfer of permanganate ion ${ }^{37}$ was investigated across the water-nitrobenzene interface with reported potential transfer, Gibbs energy of transfer, the transfer rate constant and the apparent $\alpha$ coefficient (symmetry factor equivalent in the redox electrochemistry) of this reaction. The ion transfer in this case is quasireversible, because following the permanganate transport into the organic phase a chemical reaction occurs. The kinetic parameters were obtained by cyclic voltammetry and chronopotentiometric techniques.

For many applications and even for theoretical calculations dealing with $\mathrm{L} /$ L interface it is necessary to know the diffusion coefficients and the transferring species and also the effective charges of the transferred species. Yuan et al ${ }^{38}$. demonstrated how to do this by a chronoamperometric method. To this end they employed a micropipette electrode. Since the micropipette has a large time constant (due to high resistance and relative large capacitance of the thin glass surrounding the pipette), only measurements at times more than $5 \mathrm{~ms}$ were possible. The authors performed finite element simulation to show validity of the experimental data. For protamine they determined diffusion coefficient to be $(1.2 \pm 0.1) \times 10^{-6} \mathrm{~cm}^{2} / \mathrm{s}$, with ionic charge $+20 \pm 1$, which is close to the excess positive charge of the molecule. For the ETH129 calcium ionophore they determined that each ETH molecule ${ }^{39}$ transfers +0.67 charge per each $\mathrm{Ca}^{2+}$ ion, and +1 charge per $\mathrm{Mg}^{2+}$ transfer, which corresponds to formation of 1:3 complex for calcium and 1:2 complex for magnesium, in agreement with other measurements. They also ${ }^{40}$ introduced the ionophore dinonylnaphthalenesul fonate to facilitate transport of protamine at the $\mathrm{L} / \mathrm{L}$ (water/dichloroethane) interface.

The facilitated transport is very useful in situation where the ion itself falls outside the potential window of the supporting electrolytes, usually because it is too hydrophilic. To make the ion more oil soluble, complexation with large, usually neutral species, is performed. Besides the already mentioned analytical application $\mathrm{s}^{32}$ many other determinations with facilitated transport were reported, of which only selected few can be mentioned ${ }^{16,41-49}$. Biological, physiological and pharmaceutical applications

Antibiotics are one class of compounds that have enjoyed particular attention of the analytical work on the $\mathrm{L} / \mathrm{L}$ interfaces. The typical function of an antibiotic involves facilitated transport of ions (even though, it is actually the ions, that facilitate the transport of the antibiotics) across a biological membrane. Therefore, antibiotics with appropriate modification will be transported across the ITIES. One of the early work demonstrated determination of monensin, useful in synthesis of this compound for cattle feed $^{50-54}$, or nigericis ${ }^{55,56}$. Valinomycin, which forms very selective complex with potassium, was studied on such ITIES ${ }^{57-63}$ as were $\beta$-lactam antibiotics and their derivatives ${ }^{64}$, the channel former alamecithin ${ }^{65}$. It is not without interest that antibiotics can be also synthesized, using a two phase method, on a liquidliquid interface ${ }^{66,67}$

The interface is also a natural site where polar and in particular large molecules can be absorbed. Phospoholipids ${ }^{68-71}$, phosphatidylcholine ${ }^{21,}, 72$ ${ }^{74}$, acetylcholine ${ }^{75-77}$, cellular protein annexin ${ }^{78}$, and proteins (bovine serum albumin), were all studied.

Jänchenová et $a l^{23,24}$, studied adsorption and ion pairing interactions of phospholipids on the water-1,2-dichloroethane interface. In particular, they were interested in dipalmitoyl phosphatidyl choline (DPPC) (L- $\alpha$-lecithin), which appears to have rather complex behavior.

The authors propose the following sequence of $\operatorname{steps}^{23}$.

$\mathrm{L}_{(\mathrm{o})}^{\forall} \equiv \mathrm{L}_{(\mathrm{abs})}^{\forall}+\mathrm{H}_{(\mathrm{w})}^{+} \equiv \mathrm{HL}_{(\mathrm{ads})}^{+} \equiv \mathrm{HL}_{(\mathrm{o})}^{+}+\mathrm{A}_{(\mathrm{o})}^{-} 6 \mathrm{HLA}_{(\mathrm{o})} 6 \mathrm{HA}_{(\mathrm{o})}+\mathrm{L}_{(\mathrm{o})}^{\forall}$

where $\mathrm{L}^{\forall}$ is the zwitterionic form of DPPC and $\mathrm{HL}^{+}$is its protonated form. The five steps indicate that the process depends both on the potential difference on the interface as well as the $\mathrm{pH}$ value. In the absence of multivalent ions a monolayer is formed. However, in the presence of cerium(IV) sulfate it was found that the DPPC forms multilayers, as indicated by slow transport. In fact, the multilayers strongly slow down, even prevent, the transport of larger ions such as $\mathrm{TMeA}^{+}, \mathrm{PF}_{6}^{-}$, or $\mathrm{K}^{+}$complexed with a crown-ether. Studies of such biologically important compounds as dopamine ${ }^{79}$ and promazine ${ }^{80}$ were also described.

Amemia presented several analytical papers where the property of the $\mathrm{L} / \mathrm{L}$ interface was used to detect species of biological importance. $\operatorname{In}^{81}$ he demonstrated how meparin, negatively charged polysaccharide, can be detected on the 1,2-dichloroethane interface. The detection requires use of ionophores to accomplish the transfer. One of the more successful ionophores was octadecyl trimethylammonium ion (as bromide). Unlike nonionic ionophore, this cationic 
ionophore function is potential-dependent. To further increase detection limit, the authors used preconcentration stripping method and achieved detection limit of $0.012 \mathrm{unit} / \mathrm{ml}$, significantly less than is the therapeutic (anticoagulant) value $(>0.2 \mathrm{unit} / \mathrm{ml}) . \mathrm{In}^{82}$ he used protamines as a model species to demonstrate, first time ever, voltammetric observation of phase transfer of biological polyions at water-nitrobenzene interfaces.

The smooth, unrestrained liquid/liquid interface is of great advantage in the $\mathrm{x}$-ray studies on ITIES and it is certainly of some advantage in electroanalytical applications where the surface area is that of the geometrical area. However, in applications where large surface area is needed, such as in phase transfer catalysis or in the use for energy applications in possible solar cells ${ }^{82-87}$, the limited surface area is a problem. Girault et a $l^{88}$ demonstrated that increase in surface are can be performed when a 3-dimensional ITIES experiment is performed on vitreous carbon.

An interesting nanotechnology procedure using liquid-liquid interfaces was demonstrated by Glaser $e t$ a $l^{89}$, where the hexane-water interface was used to align forming particles in a manner that a particle sphere consisting from two different materials, one on each side, is formed. These particles, called Janus particles after the Greek god with a face both on front and back of his head, were formed from simultaneous growth of $\mathrm{Au}$ and $\mathrm{Fe}_{3} \mathrm{O}_{4}$. At least theoretically Kornyshev et $a l^{90}$ suggested a principle of operation of a molecular device on ITIES that could transform the energy of light into repetitive mechanical motion.

When Nernst ${ }^{91,92}$ postulated the thermodynamic basis for electrode equilibrium potential, leading now to what is known as the Nernst equation, he also carried out with Riesenfeld experiments on liquid/liquid interfaces ${ }^{93}$. However, early work on liquid interfaces was mostly non-electrochemical, focusing on extraction processes, salting-out in ion solvent extraction, measurements of physical properties such as interfacial tension, and physiological studies on model membranes ${ }^{94-102}$. Systematic electrochemical treatment did not begin until the late 1970's when Koryta et a ${ }^{103}$ demonstrated that the liquid/liquid interface lends itself to the same formalism as a solution/ metal interface and that similar, if not identical, experimental methodology could be used. This led soon to development of various electrochemical techniques to study the liquid/liquid interface, including, among others, studies of the solvent dropping interface ${ }^{103-108}$, and studies of cyclic voltammetry ${ }^{108}$, impedance measurements ${ }^{109-112}$, drop pressure method ${ }^{113}$, galvanostatic pulse method $^{114,115}$, stripping voltammetry ${ }^{114}$, voltfluorometry ${ }^{116-119}$, and transport across a microinterface ${ }^{120-125}$. Electron transfer and photoinduced electron transfer have been also observed on ITIES or theoretically treated ${ }^{19,84,86,87,126-}$ ${ }_{133}$, as well as electrochemical catalysis ${ }^{19,}$ 126, 127, 134, 135 , adsorption $^{15,72,136-138}$ and electrodeposition ${ }^{26,139-154}$.

Newer techniques have been more recently applied to ITIES, such as the quartz crystal microbalance ${ }^{155,156}$, and scanning electrochemical microscopy on liquid/liquid interfaces ${ }^{75,157-161}$.

Although the field of liquid/liquid electrochemistry is still relatively new, more scientists are finding its results or methodology relevant and important to their own work ${ }^{27-29}$. Recent efforts have led to many practical applications in analytical chemistry and electrochemistry ${ }^{162,163}$. Charge transport across an interface between two immiscible ionically conductive media is very important both in naturally occurring systems and in designed applications. Examples include ion transport across biological membranes ${ }^{15,164,165}$, drug delivery ${ }^{166}$, behavior of ion-selective electrodes with liquid membranes and similar sensors ${ }^{167}$, extraction processes in oil recovery ${ }^{168}$ or nuclear waste reclamation and recovery ${ }^{169,170}$, phase transfer catalysis in organic synthesis ${ }^{171}$, pharmacology ${ }^{172-174}$, and many applications in electroanalytical chemistry ${ }^{130,} 163$, ${ }^{174-178}$, applied or developmental. Fundamentally, the interface is equivalent to one side of a membrane of an ion selective electrode and thus these studies usually draw on the work of ITIES as well. Microinterfaces are another useful analytical tool, one already used to build sensors ${ }^{179}$ or to be used in the scanning pipette electrochemical microscopy ${ }^{180-182}$ or in other analytical detection schemes ${ }^{121,183-186}$. Ionic liquids which recently gained popularity in chemistry research also show promise for applications in the ITIES work ${ }^{187-193}$

Studies of charge transport, mostly ion but also electron, across the liquid/ liquid interface are often interpreted in terms of molecular or ionic ordering at the interface. Both computer simulations and analytic theories aiming to understand these electrochemical studies predict or assume very often existence of molecular ordering at the interface ${ }^{27,28,193}$. However, there are few techniques that are capable to probe directly this interface on the molecular length scale. Such techniques include surface second harmonic generation ${ }^{137,194-203}$, totalinternal reflection spectroscopy ${ }^{204-207}$, ac-potential modulation spectroscopy ${ }^{84}$ ${ }^{197}$, vibrational sum-frequency spectroscopy ${ }^{208}$, and time-resolved quasi-elastic light scattering ${ }^{209}$, as well as neutron reflectivity ${ }^{210-213}$. To answer fundamental questions about the structure and transport across this interface on the molecular length scale a method using X-ray surface scattering was developed ${ }^{214-219}$. This $\mathrm{X}$-ray method provides information on interfacial molecular ordering on the sub-nanometer length scale that is complementary to that provided by the electrochemical and optical techniques.

\section{Fundamental Studies}

Electron transfer. Most of the analytical applications deal with transport of ions across the interface, either directly or in some facilitated form using a ligand to adjust the Gibbs energy of transport appropriately to fit into the potential window. In fact, in the introduction we have made a clear distinction between metal electrode and solution and an interface between the electrolytes, and we pointed out that there is no redox reaction taking place at the ITIES. However, in addition to ion transport across the ITIES, is also possible to observe processes involving electron transfer. Such processes typically require one redox system in each of the two phases and then the electron transfer can occur on the interface. The redox couples used were for example ferroceneferricinium for the nonaqueous phase and ferri-ferrocyanide in the aqueous phase $^{220}$. Other work investigating transport of electrons on ITIES, using microinterfaces and scanning electrochemical micropipette methods, were reported $^{127,130,220-229}$.

Interfacial Structure of Pure Interfaces. There are essentially two basic, but opposing views of the structure of the interfacial structure of the liquid/liquid boundary. One model predicts a molecularly sharp interface only disturbed by contribution from capillary wave fluctuations. The other model assumes interface in which regions of molecules originating from both phases exist. These two views result in two very different chemical environments for molecules at the interface. Interfacial tension and electrical capacitance measurements at the interface between two electrolyte solutions have provided arguments both for and against the sharp interfacial region ${ }^{128,230-237}$.

Either view of the interfacial structure has also appeared in the theoretical literature ${ }^{129}, 132,133$. These studies include a density functional approach that leads to a mixed interfacial region at the interface with a thickness of several solvent diameters ${ }^{238}$ and lattice-gas calculations that incorporate a mixed interfacial region whose thickness is proportional to the miscibility of the two solvents ${ }^{237,239}$. Computer simulations based on molecular dynamics predict that the interface should be locally sharp, only roughened by capillary waves ${ }^{214-240-}$ ${ }^{247}$ that originate form thermal movement of all particles in the matter.

The sharpness of the interface is not only a matter of academic curiosity. It has also important practical electrochemical consequences. For example, Marcus calculated rate constants for electron transfer between two redox species in opposite phases, using either the sharp or the diffuse interface model ${ }^{131,132}$. His two results differed by two orders of magnitude. However, at that time the scarce experimental data available and their experimental uncertainty, failed to provide definitive answers to the question of the interfacial structure ${ }^{129}$.

The cause of disagreement on the nature of the interfacial structure was in part due to a lack of techniques that can directly probe the interface. Interfacial tension and capacitance, which were both used, probe only macroscopic properties of the interface. The interfacial width of a nearly pure interface, DCE/water $(0.05 \mathrm{M} \mathrm{KOH})$, which was measured by neutron reflectivity, was found to be less than or equal to $1000 \mathrm{pm}^{210}$. A vibrational sum-frequency spectroscopy was used to study the DCE/water interface and it measured a small optical response from polarization normal to the interfacial plane. Although this result was interpreted as evidence for a mixed interfacial region, this technique does not directly measure the interfacial width ${ }^{208}$. Schlossman et al. used X-ray reflectivity to measure the width of the 2-heptanone/water interface to be $700 \pm 20 \mathrm{pm}^{215}$, which agrees well with the value $730 \mathrm{pm}$ predicted from capillary wave theory. This theory describes a fluctuating, molecularly sharp interface. Molecular dynamics simulations are also in quantitative agreement with Schlossman et al. results ${ }^{244}$. Schlossman et al. also measured the width of the nitrobenzene/water interface at four different temperatures ${ }^{214,216}$. It turns out that the measured interfacial width is actually significantly smaller than the one 
calculated from the capillary wave theory. For example, at $25^{\circ} \mathrm{C}$ the measured width is $450 \pm 10 \mathrm{pm}$ and the prediction is $520 \mathrm{pm}$. To explain this discrepancy, the computer simulations suggest the presence of both weak molecular layering (of nitrobenzene at the interface) as well as dipole ordering parallel to the interface ${ }^{244}$. It was shown that either layering or a bending rigidity, which could result from dipole ordering, could explain these measurements ${ }^{214}$. The spatial resolution of the measurements did not allow to distinguish between these two possibilities. However, these results unequivocally demonstrate that the interface is molecularly sharp.

If the model of a mixed solvent region at the interface would apply, the width of the interfacial region would have a contribution both from thermal fluctuations (capillary waves) as well as from the thickness of the mixed region. These effects would lead, however, to a substantially larger width than was measured. Therefore, the results ${ }^{214}$ are not consistent with the theory of a mixed solvent region. A recent measurement on water/hexane interface using neutron reflectivity ${ }^{248,249}$ confirmed X-ray results done on the same interface ${ }^{250}$. Although the water/hexadecane interface cannot be used for liquid/liquid electrochemistry, the agreement of the results from both methods (X-rays, $600 \pm 20 \mathrm{pm}$; neutrons, $600 \pm 10 \mathrm{pm})$ confirm soundness of the reflectivity measurements methods.

The interface between two liquid can have unusual electrowetting properties $^{251}$. In fact, unusual effect of interfacial motion related to this effect has been described by many before ${ }^{252-259}$.

Ion Distributions at Interfaces. The liquid-liquid interface has two important advantages over other interfaces if one wants to study ion distribution near a surface. First is that the fluid interface does not impose an external structure on the adjacent liquid, unlike what would be expected from atomic size patterns on a solid surface. Second, if a solid surface or even a Langmuir monolayer on the water surface were to be used, their own bound charges, which are not known, would have to be separately determined.

Ion distributions near a charged, planar surface can be predicted to some degree by Gouy-Chapman theory, which solves the Poisson-Boltzmann equation with simplifying assumptions ${ }^{260,261}$. One limitation of this theory is that it assumes point-like volume-less ions, which interact through their mean field in a structureless, continuum solvent. Extensive development and modification of the theory has addressed the limitations of the Gouy-Chapman theory ${ }^{262}$ and predicted that for monovalent ions the deviations are largely a result of the difference between the interfacial and the bulk liquid structure. However, only few experimental probes are directly sensitive to the structure near the charged interface, and the limit of validity of Gouy-Chapman theory has not been properly tested. The X-ray structural measurements, which demonstrate the failure of the Gouy-Chapman theory, are in agreement with predictions based upon a molecular dynamics simulation that includes the effects of interfacial liquid structure ${ }^{217}$.

Classical electrochemical measurements at the liquid/liquid interface have revealed inadequacies of the Gouy-Chapman theory as well ${ }^{139}, 233,234,237,263-268$. A so-called Stern layer of preferentially adsorbed solvent molecules or ions is often used to explain measurements at the electrode/solution interface ${ }^{269}$. The modified Gouy-Chapman-Stern theory includes the adsorbed layer plus the diffuse ion distribution described by the original Gouy-Chapman theory. Preferential adsorption of ions can occur at the liquid-liquid interface, although tension measurements show that this does not occur on the nitrobenzene with TBATPB and water with TBABr ${ }^{231}$.

\section{CONCLUSIONS}

It was out intention to outline the principle of the ITIES in electrochemistry and to highlight some more recent or pressing aspects of this field. For better in-depth understanding several larger reviews are available $10,129,138,271-274$.

\section{ACKNOWLEDGEMENTS}

PV acknowledges support from NSF-CHE0315691.

Basáez agradece al proyecto DIUC $\mathrm{N}^{\circ} 207.021 .025-1.0$ and DIUC $\mathrm{N}^{\circ}$ 208.021.025-1.0

\section{About the authors:}

Luis Basáez Ramírez is Assistant Professor at the Department of Analytical and Inorganic Chemistry, University of Concepción, Casilla 160-C, Concepción, Chile. He received his Ph.D. in 1995 from the Catholic University of Valparaiso. He is presently appointed at the University of Concepción, in 1996-2001 as an Instructor and since 2001 as an Assistant Professor.

Petr Vanýsek is a Professor at the Chemistry and Biochemistry Department of Northern Illinois University. His interests are in the field of liquid interfaces as well as sensors, impedance studies in general and in particular impedance studies on components of fuel cell. He is particularly interested in interpreting the impedance data correctly, with emphasis on unearthing experimental artifacts. He is the Secretary of the Electrochemical Society and the Regional Representative (USA) of the International Society of Electrochemistry. He received his Ph.D. in Physical Chemistry from the Czechoslovak Academy of Sciences in Prague.

\section{REFERENCES}

1. B. Behr, J. Gutknecht, H. Schneider, J. Stroka, J. Electroanal. Chem. 86, 289, (1978).

2. H. H. Girault, http://lepa.epfl.ch/cgi/DB/InterrDB.pl. (Page verified active 17 April 2008).

3. M. H. Abraham, T. Hill, H. C. Ling, R. A. Schultz, R. A. C. Watt, J. Chem. Soc., Faraday Trans. I. 80, 489, (1984).

4. O. Popovych, Crit. Rev. Anal. Chem. 1, 73, (1970).

5. J. Rais, Collect. Czech. Chem. Commun. 36, 3253, (1971).

6. A. J. Parker, Chem. Rev. 69, 1, (1969).

7. D. J. Fermin, H. D. Duong, Z. Ding, P.-F. Brevet, H. H. Girault, Phys. Chem. Chem. Phys. 1, 1461, (1999).

8. L. Q. Hung, J. Electroanal. Chem. 115, 159, (1980).

9. P. Vanysek. Determination of Gibbs energies of transfer of extremely lipophilic supporting electrolytes in liquidliquid electrochemistry. in The 58th Annual Meeting of the International Society of Electrochemistry. 2007. Banff: ISE.

10. B. D'Epenoux, P. Seta, G. Amblard, C. Gavach, J. Electroanal. Chem. 99, 77, (1979).

11. P. Vanysek, Electrochemistry on Liquid/Liquid Interfaces. Lecture Notes in Chemistry, ed. G. Berthier. Vol. 39. Springer-Verlag. Berlin. 1985, 106 pp.

12. A. K. Kontturi, L. Kontturi, J. A. Manzanares, S. Mafe, L. Murtomaeki, Ber. Bunsen-Ges. Phys. Chem. 99, 1131, (1995).

13. R. D. Webster, D. Beaglehole, Phys. Chem. Chem. Phys. 2, 5660, (2000).

14. S. Senthilkumar, R. A. W. Dryfe, R. Saraswathi, Langmuir. 23, 3455, (2007).

15. S. Amemiya, X. Yang, T. L. Wazenegger, J. Am. Chem. Soc. 125, 11832, (2003).

16. M. H. M. Cacote, C. M. Pereira, L. Tomaszewski, H. H. Girault, F. Silva, Electrochim. Acta. 49, 263, (2004).

17. B. L. Rivas, S. Villegas, B. Ruf, I. M. Peric, J. Chil. Chem. Soc. 52, 1164 , (2007).

18. V. Gobry, G. Bouchard, P.-A. Carrupt, B. Testa, H. H. Girault, Helv. Chim. Acta. 83, 1465, (2000).

19. R. Lahtinen, H. Jensen, D. J. Fermin, Catalysis and photocatalysis at polarized molecular interfaces. An electrochemical approach to catalytic processes based on two-phase systems, self-organized microheterogeneous structures, and unsupported nanoparticles, in Interfacial Catalysis, A. G. Volkov, Editor. CRC Press, Boca Raton, 2003, p. 611.

20. C. Gamboa, R. Barraza, A. F. Olea, J. Chil. Chem. Soc. 49, 303, (2004).

21. T. Kakiuchi, T. Kondo, M. Kotani, M. Senda, Langmuir. 8, 169, (1992).

22. Y. Yoshida, K. Maeda, O. Shirai, J. Electroanal. Chem. 578, 17, (2005).

23. H. Jaenchenova, A. Lhotsky, K. Stulik, V. Marecek, J. Electroanal. Chem. 601, 101, (2007)

24. H. Jaenchenova, K. Stulik, V. Marecek, J. Electroanal. Chem. 604, 109, (2007).

25. G. Moakes, J. Janata, Acc. Chem. Res. 40, 720, (2007).

26. A. Trojanek, J. Langmaier, Z. Samec, J. Electroanal. Chem. 599, 160 , (2007).

27. A. G. Volkov, D. W. Deamer, Liquid-Liquid Interfaces: Theory and Methods. 1996, 421 pp. 
28. A. G. Volkov, Editor, Liquid Interfaces in Chemical, Biological, and Pharmaceutical Applications. [In: Surfactant Sci. Ser., 2001; 95]. 2001, $853 \mathrm{pp}$.

29. H. Watarai, N. Teramae, T. Sawada, Editors, Interfacial Nanochemistry: Molecular Science and Engineering at Liquid-Liquid Interfaces. 2005, $321 \mathrm{pp}$.

30. H. H. Girault, Analytical and physical electrochemistry. EPFL Press. Lausanne, Switzerland. 2004 pp.

31. A. W. Bott, S. W. Feldberg, M. Rudolph, Curr. Sep. 13, 108, (1995).

32. Z. Sun, P. Vanysek, Anal. Chim. Acta. 228, 241, (1990).

33. A. Berduque, M. D. Scanlon, C. J. Collins, D. W. M. Arrigan, Langmuir. 23, 7356, (2007)

34. A. Oliva, A. Molinari, C. Avila, M. F. Flores, J. Chil. Chem. Soc. 51, 865, (2006).

35. C. G. Gomez, C. R. von Plessing, G. M. C. Godoy, R. H. Reinbach, R. R. Godoy, J. Chil. Chem. Soc. 50, 479, (2005).

36. V. K. Jain, S. G. Pillap, H. C. Mandal, J. Chil. Chem. Soc. 52, 1177, (2007).

37. H. Heli, M. Shamsipur, M. F. Mousavi, Pol. J. Chem. 80, 313, (2006).

38. Y. Yuan, L. Wang, S. Amemiya, Anal. Chem. 76, 5570, (2004).

39. U. Schefer, D. Ammann, E. Pretsch, U. Oesch, W. Simon, Anal. Chem. 58, 2282, (1986).

40. Y. Yuan, S. Amemiya, Anal. Chem. 76, 6877, (2004).

41. Y. Shao, M. V. Mirkin, Anal. Chem. 70, 3155, (1998).

42. R. Zazpe, C. Hibert, J. O'Brien, Y. H. Lanyon, D. W. M. Arrigan, Lab Chip. 7, 1732, (2007).

43. P. O' Dwyer, V. J. Cunnane, J. Electroanal. Chem. 581, 16, (2005).

44. G. Pieruz, P. Grassia, R. A. W. Dryfe, Desalination. 167, 417, (2004).

45. B. Kralj, R. A. W. Dryfe, J. Electroanal. Chem. 560, 127, (2003).

46. D. Zhan, Y. Xiao, Y. Yuan, Y. He, B. Wu, Y. Shao, J. Electroanal. Chem. 553, 43, (2003).

47. M. V. Manzanares, Rev. Soc. Quim. Mex. 47, 66, (2003)

48. Y. Yatziv, I. Turyan, D. Mandler, J. Am. Chem. Soc. 124, 5618, (2002).

49. Y. Kitatsuji, Z. Yoshida, H. Kudo, S. Kihara, J. Electroanal. Chem. 520, $133,(2002)$

50. J. Koryta, W. Ruth, P. Vanysek, A. Hofmanova, Anal. Lett. 15, 1685, (1982).

51. G. Du, J. Koryta, W. Ruth, P. Vanysek, J. Electroanal. Chem. 159, 413, (1983).

52. V. Marecek, H. Janchenova, M. Brezina, M. Betti, Anal. Chim. Acta. 244, 15, (1991).

53. Z. Pang, D. Guo, X. Teng, E. Wang, Chin. J. Pharm. Anal. 5, 209, (1985).

54. J. Koryta, G. Du, W. Ruth, P. Vanysek, Faraday Discuss., 209, (1984).

55. A. Sabela, J. Koryta, O. Valent, J. Electroanal. Chem. 204, 267, (1986).

56. J. Koryta, Wiad. Chem. 44, 579, (1990).

57. P. Vanysek, W. Ruth, J. Koryta, J. Electroanal. Chem. 148, 117, (1983).

58. I. Koryta, N. Kozlov Iu, A. Gofmanova, V. Khalil, P. Vanysek, Antibiotiki. 28, 810, (1983).

59. H. Ohde, K. Maeda, O. Shirai, Y. Yoshida, S. Kihara, J. Electroanal. Chem 438, 139, (1997).

60. E. Makrlik, P. Vanura, J. Halova, Pol. J. Chem. 81, 1531, (2007).

61. E. Makrlik, P. Vanura, Acta Chim. Slov. 54, 375, (2007).

62. E. Makrlik, P. Vanura, J. Radioanal. Nucl. Chem. 268, 641, (2006).

63. E. Makrlik, P. Vanura, J. Radioanal. Nucl. Chem. 268, 155, (2006)

64. L. Basaez, P. Vanysek, J. Pharm. Biomed. Anal. 19, 183, (1999).

65. D. P. Tieleman, H. J. C. Berendsen, M. S. P. Sansom, Biophys. J. 80, 331, (2001).

66. A. Illanes, L. Wilson, O. Corrotea, L. Tavernini, F. Zamorano, C. Aguirre, J. Mol. Catal. B Enzym. 47, 72, (2007).

67. C. Aguirre, P. Opazo, M. Venegas, R. Riveros, A. Illanes, Process Biochem. (Amsterdam). 41, 1924, (2006).

68. T. Kondo, T. Kakiuchi, M. Senda, Biochim. Biophys. Acta. 1, (1992).

69. L. Murtomaki, J. A. Manzanares, S. Mafe, K. Kontturi, Surf. Sci. Ser. 95 , 533, (2001).

70. Z. Samec, A. Trojanek, P. Krtil, Faraday Discuss. 129, 301, (2005).

71. J. Koryta, L. Q. Hung, A. Hofmanova, Stud. Biophys. 90, 25, (1982).

72. Z. Samec, A. Trojanek, H. H. Girault, Electrochem. Commun. 5, 98, (2003).

73. H. H. J. Girault, D. J. Schiffrin, J. Electroanal. Chem. 179, 277, (1984).

74. T. Kakiuchi, M. Kotani, J. Noguchi, M. Nakanishi, M. Senda, J. Colloid Interface Sci. 149, 279, (1992).
75. R. Gulaboski, C. M. Pereira, M. N. D. S. Cordeiro, I. Bogeski, E. Ferreira, D. Ribeiro, M. Chirea, A. F. Silva, J. Phys. Chem. B. 109, 12549, (2005).

76. B. Yu, B. Huang, P. Li, Microchem. J. 52, 10, (1995).

77. V. Marecek, Z. Samec, Anal. Lett. 14, 1241, (1981).

78. E. Bitto, M. Li, A. M. Tikhonov, M. L. Schlossman, W. Cho, Biochemistry. 39, 13469, (2000).

79. A. Berduque, R. Zazpe, D. W. M. Arrigan, Anal. Chim. Acta. 611, 156, (2008).

80. L. M. A. Monzon, L. M. Yudi, Electrochim. Acta. 53, 2217, (2008).

81. J. Guo, Y. Yuan, S. Amemiya, Anal. Chem. 77, 5711, (2005).

82. S. Amemiya, X. Yang, T. L. Wazenegger, J. Am. Chem. Soc. 125, 11832 , (2003).

83. D. J. Fermin, Z. Ding, H. D. Duong, P. F. Brevet, H. H. Girault, Chem. Commun., 1125, (1998)

84. D. J. Fermin, Z. Ding, H. D. Duong, P.-F. Brevet, H. H. Girault, J. Phys. Chem. B. 102, 10334, (1998).

85. D. J. Fermin, H. D. Duong, Z. Ding, P. F. Brevet, H. H. Girault, Electrochem. Commun. 1, 29, (1999).

86. D. J. Fermin, H. Dung Duong, Z. Ding, P. F. Brevet, H. H. Girault, Phys. Chem. Chem. Phys. 1, 1461, (1999).

87. D. J. Fermin, H. D. Duong, Z. Ding, P.-F. Brevet, H. H. Girault, J. Am. Chem. Soc. 121, 10203, (1999).

88. S. Tan, M. Hojeij, B. Su, G. Meriguet, N. Eugster, H. H. Girault, $J$. Electroanal. Chem. 604, 65, (2007).

89. N. Glaser, D. J. Adams, A. Boeker, G. Krausch, Langmuir. 22, 5227, (2006).

90. A. A. Kornyshev, M. Kuimova, A. M. Kuznetsov, J. Ulstrup, M. Urbakh, J. Phys.: Condens. Matter. 19, 375111/1, (2007).

91. W. Nernst, Z. Phys. Chem. (Frankfurt). 2, 613, (1888).

92. W. Nernst, Z. Phys. Chem. (Frankfurt). 4, 129, (1889).

93. W. Nernst, E. H. Riesenfeld, Ann. Phys. 8, 600, (1902).

94. P. Bothorel, C. Lussan, C. R. l'Academie. Sci. 266, 2492, (1968).

95. W. D. Harkins, E. C. Humphery, J. Am. Chem. Soc. 38, 228, (1916).

96. G. C. H. Ehrensvard, D. F. Cheesman, Svensk Kem. Tid. 53, 126 , (1941).

97. E. K. Fischer, W. D. Harkins, J. Phys. Chem. 36, 98, (1932).

98. T. R. Bolam, J. Crowe, J. Phys. Chem. 35, 1448, (1931).

99. R. P. Bell, J. Phys. Chem. 32, 882, (1928).

100. P. L. du Nouy, C. R. l'Academie. Sci. 180, 1579, (1925).

101. J. H. Mathews, A. J. Stamm, J. Am. Chem. Soc. 46, 1071, (1924).

102. W. D. Harkins, E. C. Humphery, J. Am. Chem. Soc. 38, 236, (1916).

103. J. Koryta, P. Vanysek, M. Brezina, J. Electroanal. Chem. 67, 263, (1976).

104. J. Koryta, P. Vanysek, M. Brezina, J. Electroanal. Chem. 75, 211, (1977).

105. P. Vanysek, J. Electroanal. Chem. 121, 149, (1981).

106. J. Koryta, M. Brezina, A. Hofmanova, D. Homolka, H. Le Quoc, W. Khalil, V. Marecek, Z. Samec, S. K. Sen, et al., Bioelectrochem. Bioenerget. 7, 61, (1980).

107. P. Vanysek, M. Behrendt, J. Electroanal. Chem. 130, 287, (1981).

108. D. Homolka, L. Q. Hung, A. Hofmanova, M. W. Khalil, J. Koryta, V. Marecek, Z. Samec, S. K. Sen, P. Vanysek, J. Weber, Anal. Chem. 52, $1606,(1980)$

109. Z. Samec, V. Marecek, D. Homolka, J. Electroanal. Chem. 126, 121, (1981).

110. T. Wandlowski, S. Racinsky, V. Marecek, Z. Samec, J. Electroanal. Chem. 227, 281, (1987).

111. T. Wandlowski, V. Marecek, Z. Samec, J. Electroanal. Chem. 242, 277, (1988).

112. P. Vanysek, I. C. Hernandez, J. Xu, Microchem. J. 41, 327, (1990).

113. J. D. Reid, O. R. Melroy, R. P. Buck, J. Electroanal. Chem. 147, 71, (1983).

114. V. Marecek, Z. Samec, Anal. Chim. Acta. 151, 265, (1983).

115. V. Marecek, Z. Samec, J. Electroanal. Chem. 149, 185, (1983).

116. T. Kakiuchi, Y. Takasu, Anal. Chem. 66, 1853, (1994).

117. T. Kakiuchi, Y. Takasu, J. Electroanal. Chem. 365, 293, (1994).

118. T. Kakiuchi, Y. Takasu, J. Electroanal. Chem. 381, 5, (1995).

119. H. Nagatani, S. Suzuki, D. J. Fermin, H. H. Girault, K. Nakatani, Anal. Bioanal. Chem. 386, 633, (2006).

120. J. A. Campbell, H. H. Girault, J. Electroanal. Chem. 266, 465, (1989).

121. A. A. Stewart, G. Taylor, H. H. Girault, J. McAleer, J. Electroanal. Chem. 296, 491, (1990). 
122. A. A. Stewart, Y. Shao, C. M. Pereira, H. H. Girault, J. Electroanal. Chem. 305, 135, (1991).

123. Y. Shao, H. H. Girault, J. Electroanal. Chem. 334, 203, (1992).

124. T. Ohkouchi, T. Kakutani, T. Osakai, M. Senda, Anal. Sci. 7, 371, (1991).

125. V. Sladkov, V. Guillou, S. Peulon, M. L'Her, J. Electroanal. Chem. 573, 129, (2004)

126. R. M. Lahtinen, D. J. Fermin, H. Jensen, K. Kontturi, H. H. Girault, Electrochem. Commun. 2, 230, (2000).

127. D. J. Fermin, R. Lahtinen, Surf. Sci. Ser. 95, 179, (2001).

128. H. H. J. Girault, D. J. Schiffrin, J. Electroanal. Chem. 244, 15, (1988).

129. G. Geblewicz, D. J. Schiffrin, J. Electroanal. Chem. 244, 27, (1988).

130. M. L'Her, V. Sladkov, Electron transfer at the liquid-liquid interface, in Trends in Molecular Electrochemistry, A. J. L. Pombeiro, C. Amatore, Editors. CRC Press, Boca Raton, 2004, p. 503.

131. T. Solomon, A. J. Bard, J. Phys. Chem. 99, 17487, (1995).

132. R. A. Marcus, J. Phys. Chem. 94, 7742, (1990).

133. R. A. Marcus, J. Phys. Chem. 94, 4152, (1990).

134. Y. Shao, M. V. Mirkin, J. F. Rusling, J. Phys. Chem. B. 101, 3202 , (1997).

135. F. G. Chevallier, T. J. Davies, O. V. Klymenko, L. Jiang, T. G. J. Jones, R. G. Compton, J. Electroanal. Chem. 580, 265, (2005).

136. B. Su, N. Eugster, H. H. Girault, J. Electroanal. Chem. 577, 187, (2005).

137. J. Zhang, C. J. Slevin, L. Murtomaeki, K. Kontturi, D. E. Williams, P. R. Unwin, Langmuir. 17, 821, (2001).

138. R. R. Naujok, D. A. Higgins, D. G. Hanken, R. M. Corn, J. Chem. Soc., Faraday Trans. 91, 1411, (1995).

139. H. H. Girault, Charge transfer across liquid-liquid interfaces, in Modern Aspects of Electrochemistry, J. O. M. Bockris, B. E. Conway, R. E. White, Editors. Plenum Publishing Corp., New York, 1993, p. 1.

140. M. Vignali, R. Edwards, V. J. Cunnane, J. Electroanal. Chem. 592, 37, (2006).

141. C. Johans, R. Lahtinen, K. Kontturi, D. J. Schiffrin, J. Electroanal. Chem. 488, 99, (2000).

142. M. Platt, R. A. W. Dryfe, J. Electroanal. Chem. 599, 323, (2007).

143. Y. Luan, M. An, G. Lu, Appl. Surf. Sci. 253, 459, (2006).

144. M. Vignali, R. A. H. Edwards, M. Serantoni, V. J. Cunnane, J. Electroanal. Chem. 591, 59, (2006).

145. V. Mirceski, R. Gulaboski, J. Phys. Chem. B. 110, 2812, (2006).

146. V. Mirceski, Electrochem. Commun. 8, 123, (2006).

147. I. Turyan, M. Etienne, D. Mandler, W. Schuhmann, Electroanalysis. 17, $538,(2005)$

148. M. Platt, R. A. W. Dryfe, Phys. Chem. Chem. Phys. 7, 1807, (2005).

149. E. Tada, Y. Oishi, H. Kaneko, Electrochem. Solid State Lett. 8, C26, (2005).

150. M. Platt, R. A. W. Dryfe, E. P. L. Roberts, Electrochim. Acta. 49, 3937, (2004).

151. C. R. C. Johans, Novel routes to metal nanoparticles: electrodeposition and reactions at liquid/liquid interfaces, in Department of Chemical Technology. 2003, Helsiki University of Technology: Espoo, Finland. p. $56 \mathrm{pp}$.

152. A. Eftekhari, Appl. Surf. Sci. 227, 331, (2004).

153. E. Tada, H. Kaneko, Chem. Lett., 1306, (2000)

154. M. Guainazzi, G. Silvestri, G. Serravalle, J. Chem. Soc., Chem. Commun., 200, (1975).

155. P. Vanysek, L. A. Delia, Electroanalysis. 18, 371, (2006).

156. P. Vanysek, Proceedings of the IEEE International Frequency Control Symposium. 51, 49, (1997).

157. T. Solomon, A. J. Bard, Anal. Chem. 67, 2787, (1995).

158. T. Solomon, A. J. Bard, Bull. Chem. Soc. Ethiopia. 11, 55, (1997).

159. C. Wei, A. J. Bard, M. V. Mirkin, J. Phys. Chem. 99, 16033, (1995).

160. M. Tsionsky, A. J. Bard, M. V. Mirkin, J. Phys. Chem. 100, 17881, (1996).

161. Y. Selzer, D. Mandler, J. Electroanal. Chem. 409, 15, (1996).

162. P. Vanysek, Anal. Chem. 62, 827A, (1990).

163. F. Reymond, D. Fermin, H. J. Lee, H. H. Girault, Electrochim. Acta. 45, 2647, (2000).

164. R. B. Gennis, Biomembranes: Molecular Structure and Function. Springer. New York. 1988, 533 pp.

165. T. Spataru, N. Spataru, N. Bonciocat, C. Luca, Bioelectrochemistry. 62, 67, (2004).
166. A. Maelkiae, P. Liljeroth, A.-K. Kontturi, K. Kontturi, J. Phys. Chem. B. 105, 10884, (2001).

167. S. A. Dassie, A. M. Baruzzi, J. Electroanal. Chem. 492, 94, (2000).

168. M. J. Tupy, H. W. Blanch, C. J. Radke, Ind. Eng. Chem. Res. 37, 3159, (1998).

169. G. W. Stevens, J. M. Perera, F. Grieser, Curr. Opin. Colloid Interface. Sci. 2, 629, (1997).

170. J. Plesek, B. Gruner, S. Hermanek, J. Baca, V. Marecek, J. Janchenova, A. Lhotsky, K. Holub, P. Selucky, J. Rais, I. Cisarova, J. Caslavsky, Polyhedron. 21, 975, (2002).

171. C. Forssten, J. Strutwolf, D. E. Williams, Electrochem. Commun. 3, 619, (2001).

172. R. Gulaboski, M. N. D. S. Cordeiro, N. Milhazes, J. Garrido, F. Borges, M. Jorge, C. M. Pereira, I. Bogeski, A. H. Morales, B. Naumoski, A. F. Silva, Anal. Biochem. 361, 236, (2007).

173. L. Basaez, I. Peric, C. Aguirre, P. Vanysek, Bol. Soc. Chil. Quim. 46, 203, (2001).

174. H. Alemu, Pure Appl. Chem. 76, 697, (2004).

175. F. Reymond, H. J. Lee, J. S. Rossier, L. Tomaszewski, R. Ferrigno, C. M. Pereira, H. H. Girault, Chimia. 53, 103, (1999).

176. J. Koryta, Selective Electr. Rev. 13, 133, (1991).

177. B. Liu, M. V. Mirkin, Electroanalysis. 12, 1433, (2000).

178. Z. Samec, E. Samcova, H. H. Girault, Talanta. 63, 21, (2004).

179. B. J. Seddon, Y. Shao, J. Fost, H. H. Girault, Electrochim. Acta. 39, 783, (1994).

180. D. Zhan, X. Li, W. Zhan, F.-R. F. Fan, A. J. Bard, Anal. Chem. 79, 5225, (2007).

181. D. A. Walsh, J. L. Fernandez, J. Mauzeroll, A. J. Bard, Anal. Chem. 77, 5182, (2005).

182. P. Sun, Z. Zhang, Z. Gao, Y. Shao, Angew. Chem. Int. Ed. 41, 3445, (2002).

183. Q. Qian, G. S. Wilson, K. Bowman-James, Electroanalysis. 16, 1343, (2004).

184. Q. Qian, G. S. Wilson, K. Bowman-James, H. H. Girault, Anal. Chem. 73, 497, (2001)

185. R. Zazpe, C. Hibert, J. O'Brien, Y. H. Lanyon, D. W. M. Arrigan, Lab Chip. 7, 1732, (2007).

186. F. Quentel, C. Elleouet, V. Mirceski, V. Agmo Hernandez, M. L'Her, M. Lovric, S. Komorsky-Lovric, F. Scholz, J. Electroanal. Chem. 611, 192, (2007).

187. J. Langmaier, Z. Samec, Electrochem. Commun. 9, 2633, (2007).

188. R. Ishimatsu, N. Nishi, T. Kakiuchi, Langmuir. 23, 7608, (2007).

189. R. Ishimatsu, N. Nishi, T. Kakiuchi, Chem. Lett. 36, 1166, (2007).

190. T. Kakiuchi, Anal. Chem. 79, 6442, (2007).

191. V. A. Hernandez, F. Scholz, Electrochem. Commun. 8, 967, (2006).

192. K. Tanaka, N. Nishi, T. Kakiuchi, Anal. Sci. 20, 1553, (2004).

193. W. Schmickler, Interfacial Electrochemistry. Oxford University Press. New York. 1996, 304 pp.

194. K. L. Kott, D. A. Higgins, R. J. McMahon, R. M. Corn, J. Am. Chem. Soc. 115, 5342, (1993).

195. D. A. Higgins, R. M. Corn, J. Phys. Chem. 97, 489, (1993).

196. D. A. Higgins, R. R. Naujok, R. M. Corn, Chem. Phys. Lett. 213, 485, (1993).

197. H. Nagatani, A. Piron, P.-F. Brevet, D. J. Fermin, H. H. Girault, Langmuir. 18, 6647, (2002).

198. J. G. Frey, Second harmonic generation at liquid/liquid interfaces, in Interfacial Nanochemistry, H. Watari, N. Teramae, T. Sawada, Editors. Springer, New York, 2005, p. 1.

199. J. C. Conboy, G. L. Richmond, Electrochim. Acta. 40, 2881, (1995).

200. J. C. Conboy, G. L. Richmond, J. Phys. Chem. B. 101, 983, (1997).

201. H. H. Girault, M. Hojeij, B. Su, Abstracts of Papers, 233rd ACS National Meeting, Chicago, IL, United States, March 25-29, 2007. PHYS, (2007).

202. J. C. Conboy, G. L. Richmond, Total internal reflection second harmonic generation from the interface between two immiscible electrolyte solutions. 1995, Dep. Chem., Oregon Univ., Eugene, OR, USA. p. 15 pp.

203. R. M. Corn, R. N. Naujok, H. J. Paul, Book of Abstracts, 210th ACS National Meeting, Chicago, IL, August 20-24. COLL, (1995).

204. S. Ishizaka, N. Kitamura, Bull. Chem. Soc. Japan. 74, 1983, (2001).

205. M. J. Tupy, Protein adsorption dynamics at the oil/water interface as studied by total internal reflection fluorescence spectroscopy. 1998, University of California at Berkeley: Berkeley. p. 268 pp. 
206. J. M. Perera, G. W. Stevens, F. Grieser, Colloids Surf., A. 95, 185, (1995).

207. J. C. Conboy, J. L. Daschbach, G. L. Richmond, J. Phys. Chem., 9688, (1994).

208. D. S. Walker, M. G. Brown, C. L. McFearin, G. L. Richmond, J. Phys. Chem. B. 108, 2111, (2004)

209. H. Yui, Y. Ikezoe, T. Sawada, Anal. Sci. 20, 1501, (2004).

210. J. Strutwolf, A. L. Barker, M. Gonsalves, D. J. Caruana, P. R. Unwin, D. E. Williams, J. R. P. Webster, J. Electroanal. Chem. 483, 163, (2000).

211. J. R. P. Webster, Abstracts of Papers, 234th ACS National Meeting, Boston, MA, United States, August 19-23, 2007. PHYS, (2007).

212. A. Zarbakhsh, A. Querol, J. Bowers, M. Yaseen, J. R. Lu, J. R. P. Webster, Langmuir. 21, 11704, (2005).

213. A. Zarbakhsh, A. Querol, J. Bowers, J. R. P. Webster, Faraday Discuss. 129, 155, (2005)

214. G. Luo, S. Malkova, S. V. Pingali, D. G. Schultz, B. Lin, M. Meron, I. Benjamin, P. Vanysek, M. L. Schlossman, J. Phys. Chem. B. 110, 4527, (2006).

215. G. Luo, S. Malkova, S. V. Pingali, D. G. Schultz, B. Lin, M. Meron, T. J. Graber, J. Gebhardt, P. Vanysek, M. L. Schlossman, Electrochem. Commun. 7, 627, (2005).

216. G. Luo, S. Malkova, S. V. Pingali, D. G. Schultz, B. Lin, M. Meron, T. J. Graber, J. Gebhardt, P. Vanysek, M. L. Schlossman, Faraday Discuss. 129, 23, (2005).

217. G. Luo, S. Malkova, a. Yoon, D. G. Schultz, B. Lin, M. Meron, I. Benjamin, P. Vanysek, M. L. Schlossman, Science. 311, 216, (2006).

218. G. Luo, S. Malkova, J. Yoon, D. Schultz, B. Lin, I. Benjamin, P. Vanysek, M. L. Schlossman, Abstracts of Papers, 233rd ACS National Meeting, Chicago, IL, United States, March 25-29, 2007. PHYS, (2007).

219. G. Luo, S. Malkova, J. Yoon, D. G. Schultz, B. Lin, M. Meron, I. Benjamin, P. Vanysek, M. L. Schlossman, J. Electroanal. Chem. 593, 142, (2006).

220. T. Kakiuchi, T. Takaishi, Proceedings - Electrochemical Society. 97-19, $538,(1997)$.

221. A. A. Stewart, J. A. Campbell, H. H. Girault, M. Eddowes, Ber. BunsenGes. Phys. Chem. 94, 83, (1990).

222. X. Lu, H. Zhang, L. Hu, C. Zhao, L. Zhang, X. Liu, Electrochem. Commun. 8, 1027, (2006).

223. X. Lu, L. Hu, X. Wang, Electroanalysis. 17, 953, (2005).

224. M. V. Mirkin, M. Tsionsky, Charge-transfer at the liquid/liquid interface, in Scanning Electrochemical Microscopy, A. J. Bard, M. V. Mirkin, Editors. CRC Press, Boca Raton, 2001, p. 299.

225. J. Zhang, P. R. Unwin, Phys. Chem. Chem. Phys. 4, 3820, (2002).

226. A. L. Barker, P. R. Unwin, J. Zhang, Electrochem. Commun. 3, 372, (2001).

227. B. Quinn, K. Kontturi, J. Electroanal. Chem. 483, 124, (2000).

228. J. Zhang, A. L. Barker, P. R. Unwin, J. Electroanal. Chem. 483, 95, (2000).

229. A. L. Barker, P. R. Unwin, J. Phys. Chem. B. 104, 2330, (2000).

230. T. Kakiuchi, M. Senda, Bull. Chem. Soc. Japan. 56, 1322, (1983).

231. C. Gavach, P. Seta, B. D'Epenoux, J. Electroanal. Chem. 83, 225, (1977).

232. M. Gros, S. Gromb, C. Gavach, J. Electroanal. Chem. 89, 29, (1978).

233. Z. Samec, V. Marecek, D. Homolka, J. Electroanal. Chem. 187, 31, (1985).

234. H. H. Girault, D. J. Schiffrin, J. Electroanal. Chem. 150, 43, (1983).

235. H. H. Girault, Electrochim. Acta. 32, 383, (1987).

236. H. H. J. Girault, D. J. Schiffrin, J. Electroanal. Chem. 170, 127, (1984).

237. C. M. Pereira, W. Schmickler, A. F. Silva, M. J. Sousa, Chem. Phys. Lett. 268, 13, (1997).

238. D. J. Henderson, W. Schmickler, J. Chem. Soc., Faraday Trans. 92, $3839,(1996)$
239. S. Frank, W. Schmickler, J. Electroanal. Chem. 483, 18, (2000).

240. I. Benjamin, Science. 261, 1558, (1993).

241. I. Benjamin, Chem. Rev. 96, 1449, (1996).

242. L. Benjamin, J. Chem. Phys. 97, 1432, (1992).

243. D. Michael, I. Benjamin, J. Electroanal. Chem. 450, 335, (1998).

244. P. A. Fernandes, M. N. D. S. Cordeiro, J. A. N. F. Gomes, J. Phys. Chem. B. 103, 8930, (1999).

245. M. R. Philpott, T.-T. Lin, J. N. Glosli. Molecular Dynamics Study of Neutral and Charged Liquid-Liquid Interfaces. in Modeling of Processes at Electrochemical Interfaces and in Electrochemical Systems. 1999. Seattle: The Electrochemical Society.

246. P. Tarazona, R. Checa, E. Chacon, Phys. Rev. Lett. 99, 196101/1, (2007).

247. J. Chowdhary, B. M. Ladanyi, Abstracts of Papers, 232nd ACS National Meeting, San Francisco, CA, United States, Sept. 10-14, 2006. COLL, (2006).

248. D. M. Mitrinovic, A. M. Tikhonov, M. Li, Z. Huang, M. L. Schlossman, Phys. Rev. Lett. 85, 582, (2000).

249. A. Zarbakhsh, J. Bowers, J. R. P. Webster, Langmuir. 21, 11596, (2005).

250. M. L. Schlossman, Curr. Opin. Colloid Interface. Sci. 7, 235, (2002).

251. C. W. Monroe, M. Urbakh, A. A. Kornyshev, J. Phys.: Condens. Matter. 19,375113/1, (2007).

252. R. Chertcoff, A. Calvo, I. Paterson, M. Rosen, J. P. Hulin, J. Colloid Interface Sci. 154, 194, (1992).

253. P. Joos, R. V. Bogaert, J. Colloid Interface Sci. 56, 213, (1976).

254. M. Dupeyrat, J. Michel, Experientia Suppl. 18, 269, (1971).

255. M. Dupeyrat, E. Nakache, C. R. Acad. Sci. (Paris). 277, 599, (1973).

256. E. Nakache, M. Dupeyrat, M. Vignes-Adler, Faraday Discuss. Chem. Soc. 77, 189, (1984).

257. P. Van Remoortere, P. Joos, J. Colloid Interface Sci. 160, 397, (1993).

258. A. A. Kornyshev, A. M. Kuznetsov, M. Urbakh, J. Chem. Phys. 117, $6766,(2002)$.

259. A. L. Barker, P. R. Unwin, J. Phys. Chem. B. 105, 12019, (2001).

260. Gouy, C. R. l'Academie. Sci. 149, 654, (1910).

261. D. L. Chapman, Phil. Mag. Ser. 6. 25, 475, (1913).

262. S. Levine, C. W. Outhwaite, L. B. Bhuiyan, J. Electroanal. Chem. 123 , 105, (1981)

263. C. M. Pereira, A. Martins, M. Rocha, C. J. Silva, F. Silva, J. Chem. Soc., Faraday Trans. 90, 143, (1994).

264. Y. Cheng, V. J. Cunnane, D. J. Schiffrin, L. Murtomaki, K. Kontturi, J. Chem. Soc., Faraday Trans. 87, 1665, (1991).

265. Y. Cheng, V. J. Cunnane, D. J. Schiffrin, L. Mutomaki, K. Kontturi, J. Chem. Soc., Faraday Trans. 87, 107, (1991).

266. C. M. Pereira, W. Schmickler, F. Silva, M. J. Sousa, J. Electroanal. Chem. 436, 9, (1997).

267. O. Pecina, J. P. Badiali, Phys. Rev. E. Sta. Phys. Plasma Fluid. Rel. 58 6041, (1998)

268. H. H. Girault, D. J. Schiffrin, Electrochemistry of liquid-liquid interfaces, in Electroanalytical Chemistry, A. J. Bard, Editor. Marcel Dekker, New York, 1989 , p. 1.

269. O. Stern, Z. Elektrochem. 30, 508, (1924).

270. P. Vanysek, TrAC, Trends Anal. Chem. 12, 357, (1993).

271. A. Volkov, D. W. Deamer, eds. Liquid-Liquid Interfaces. Theory and Methods. 1st ed. CRC, Boca Raton, 1996. 448 pp.

272. A. G. Volkov, V. S. Markin, Electrochemical double lavers: liquid-liquid interfaces, in Encyclopedia of Electrochemistry. Wiley-VCH, New York, 2003, p. 162.

273. A. G. Volkov, V. S. Markin, Electric properties of oil/water interfaces, in Emulsions: Structure, stability and interactions, 4, D. Petsev, Editor. Academic Press, New York, 2004, p. 91. 